\title{
Is urban agriculture financially sustainable? An exploratory study of small-scale market farming in Philadelphia, Pennsylvania
}

Christian Hunold, ${ }^{\text {* }}$ Yetunde Sorunmu, ${ }^{\mathrm{b}}$ Rachel Lindy, ${ }^{\mathrm{b}}$ Sabrina Spatari, ${ }^{\mathrm{b}}$ and Patrick L. Gurian ${ }^{\mathrm{b}}$ Drexel University

Submitted June 8, 2016 / Revised December 5, 2016, and January 31, 2017 /

Accepted February 13, 2017 / Published online March 22, 2017

Citation: Hunold, C., Sorunmu, Y., Lindy, R., Spatari, S., \& Gurian, P. L. (2017). Is urban

agriculture financially sustainable? An exploratory study of small-scpale market farming

in Philadelphia, Pennsylvania. Journal of Agriculture, Food Systems, and Community

Development, 7(2), 51-67. http://dx.doi.org/10.5304/jafscd.2017.072.012

Copyright (C) 2017 by New Leaf Associates, Inc.

\begin{abstract}
Existing research on the economic sustainability of urban agriculture in the United States tends to emphasize a multifaceted conception of urban agriculture's return on investment as a combination of revenue and less quantifiable positive externalities. A more business-oriented advocacy literature, however, sees urban agriculture as a way to
\end{abstract}

${ }^{a}$ Department of Politics, Drexel University, Philadelphia, Pennsylvania, USA.

b Department of Civil, Architectural, and Environmental Engineering, Drexel University, Philadelphia, Pennsylvania, USA.

* Corresponding author: Christian Hunold, Department of Politics, 3025 MacAlister Hall, Drexel University, Philadelphia, Pennsylvania 19104 USA; hunoldc@,drexel.edu

Disclosure

This project was funded by Drexel University's Urban Sustainability Initiative. generate income for farmers and farm workers. The purpose of this study is twofold. First, we estimate the economic returns of urban farming in Philadelphia, Pennsylvania, based on data obtained from urban farmers involved in market farming. Here our goal is to better understand the contribution of market farming to the economic viability of urban agriculture. Second, we hope to improve understanding of how the farmers themselves perceive and navigate commensurabilities and tensions between predominantly market-oriented and more heavily social-service oriented forms of urban agriculture. Home to more than a dozen farms, Philadelphia is a suitable location for such an exploratory study of the financial sustainability of urban agriculture.

\section{Keywords}

Urban Agriculture; City Farming; Market Farming; Entrepreneurial Urban Agriculture; Profitability of Urban Agriculture 


\section{Introduction}

In the United States, studying urban agriculture as a business has not been a research priority. Existing studies of entrepreneurial city farming have emphasized an expansive conception of urban agriculture's return on investment as a combination of revenue and less quantifiable positive externalities beyond growing food (Kaufman \& Bailkey, 2000). The economic and community development literature tends to frame urban agriculture as a social enterprise (e.g., Vitiello \& Wolf-Powers, 2014), a framing that reflects many U.S. urban farmers' aspirations to advance various economic, environmental, and equity goals (Wachter, Scruggs, Voith, \& Huang, 2010). There is little argument that urban agriculture's contribution to conventional economic development goals_-attracting capital, generating income, creating jobs-will likely remain modest (Vitiello \& Wolf-Powers, 2014; Sadler, Arku, \& Gilliland, 2015). Unlike rural farms, urban agriculture spaces are designed to be multifunctional, with market farming rarely the main objective (Lovell, 2010).

That said, market farming is part of the portfolio of many urban agriculture operations. Moreover, the financial sustainability of urban agriculture would seem to be an important condition of its long-term stability and of its capacity to contribute to wider community and economic development goals. Some urban farms generate sufficient revenue from crop sales to pay their farmers and other employees a living wage, but profitable urban farms appear to be rare. On the one hand, the scarcity of profitability is unsurprising, given urban agriculture's improvisational, do-it-yourself origins, strong social enterprise mission, and the small size of most urban farms. From this perspective, urban agriculture is not about turning a profit; to treat it as a conventional entrepreneurial venture is to miss the point. On the other hand, the scarcity of profitability does raise questions insofar as urban agriculture has been advanced, for some time, as a community and economic development tool for supplementing pantries as well as wallets.

\footnotetext{
${ }^{1}$ Parts of this section have been adapted from Chapter 1 of Rachel Lindy's Mathematics-Economics honors thesis, "Carrots in Concrete and Corner Stores: Two Analyses of
}

The purpose of this study is twofold. First, we seek to estimate the economic returns of urban farming in Philadelphia, Pennsylvania, based on data obtained from urban farmers. Many, if not most, urban farms derive their income from a combination of crop sales, external grants, and ancillary activities. Our goal is to better understand the contribution of market farming to the economic viability of urban agriculture. Second, we hope to improve understanding of how the farmers themselves conceptualize and navigate the pursuit of urban farming as a profit-seeking enterprise, a social-benefiting endeavor, or both. To this end, we use the well-known small plot intensive (SPIN) farming method as a lens through which to get the farmers and farmworkers in our study to reflect on the role of market farming in urban agriculture. Our analysis of the collected quantitative and qualitative data contributes to a clearer understanding of the factors that shape the financial viability of urban agriculture in Philadelphia. Our goal is modest but important: to replace speculation about the financial sustainability of urban agriculture with empirical evidence. The data have some limitations; we cannot gauge the extent to which our findings reflect the financial reality of urban farming in other cities or that of farmers in Philadelphia who did not participate in our study.

Following a background section that describes the historical and political context of urban agriculture in Philadelphia and that connects our study to social science debates on urban agriculture, we discuss our qualitative survey research design. We then discuss our results and conclude with some policy recommendations for improving the financial sustainability of urban agriculture.

\section{Background $^{1}$}

The United States' fifth-largest city is fertile ground for exploring the financial viability of urban farming with a vibrant urban agriculture community. Following massive job and population loss associated with the deindustrialization of the mid- $20^{\text {th }}$ century, the number of community gardens in the

Tools to Mitigate Urban Food Insecurity," submitted to Wesleyan University in April 2015. 
city greatly increased in the 1970s, supported by Penn State's Urban Gardening program and the Pennsylvania Horticultural Society's Philadelphia Green program (Vitiello \& Nairn, 2009, p. 27). A significant number of these garden spaces has since been lost to development and/or the retirement or death of their caretakers. Still, in 2016, there were "at least 470 gardens on almost 600 parcels, distributed citywide and concentrated in historically disinvested neighborhoods" (Philadelphia Food Policy Advisory Council, n.d., para. 4). Included in this count are more than a dozen urban farms that engage in some form of market farming. Presentday urban market farming arguably got its start in 1998, with the founding of Greensgrow Farms on a capped Superfund brownfield in the city's Kensington section. Since then, the number of urban farms has grown, and municipal support for urban agriculture has become somewhat institutionalized. In 2007, the mayoral administration of Michael Nutter (2008-2015) was elected, in part, with a mandate to reimagine Philadelphia through the lens of an urban sustainability agenda, prompting some observers to speculate about a transformation of the city's decades-old "growth machine" governing coalition by "the progressive ideas, values, beliefs, and practices of a grassroots movement composed of middle-class residents" (McGovern, 2009, p. 663). While enthusiasm for Nutter's agenda was somewhat dampened by the Great Recession, municipal commitment to urban agriculture was reflected in the inclusion of expanding food production as a measurable policy target in the city's sustainability plan, Greenworks Philadelphia. In 2012, a revised zoning code declared gardening and farming permissible activities on most land in the city; the Philadelphia Land Bank Law of 2013 identified urban agriculture as a priority community beneficial use for vacant land; and, in 2016, City Council approved a stormwater fee exemption for gardens (Philadelphia Food Policy Advisory Council, n.d., para. 6). Several nonprofit organizations including, among others, the Pennsylvania Horticultural Society, the Food Trust, the Neighborhood Gardens Trust, and the Public Interest Law Center provide technical advice and legal resources for urban farmers while also engaging in policy advocacy. A Food Policy
Advisory Council, established in 2011, bundles expertise for urban agriculture policy development.

In terms of the recognition by government agencies and nonprofit organizations of urban agriculture as a potentially valuable community and economic development tool, Philadelphia reflects the ongoing transition from "radical" outsider role to "reformist" insider status observed across the country. A prominent (if not predominant) point of contention among social scientists concerns the capacity for urban agriculture to contribute to building a more just society, due to the individualization of poverty and the rollback of the state associated with neoliberal capitalism. This context has prompted scholars to draw very different conclusions about urban agriculture's significance. A largely celebratory perspective contends that growing their own food empowers marginalized communities to fight against systematic food injustice and food insecurity (Cockrall-King, 2012; Kingsley \& Townsend, 2006; Nordahl, 2009; Ladner, 2011; Winne, 2009). By treating urban agriculture as somehow insulated from neoliberal politics and economics, this "civic agriculture" perspective likely overstates urban agriculture's potential to redress wider societal injustices. More critical scholars, however, are often quick to discount urban agriculture as a self-limiting (if not selfdefeating) response to the privatization of social policy and the welfare state's withdrawal from economic and community development (Allen \& Guthman, 2006; Guthman, 2008). In this view, city farming projects are caught up in an endless cycle of pursuing capricious grant funding in the hope of repairing some of the wounds inflicted by deindustrialization and disinvestment. The place-based, self-help ethic of urban agriculture is left with the responsibility for the neoliberal state's withdrawal by making life in some low-wealth neighborhoods somewhat less intolerable.

Recent work in urban geography has sought to replace this bifurcation of research perspectives with a more nuanced assessment of urban agriculture's role in the struggle for urban sociopolitical and economic change (Classens, 2015; McClintock, 2014; Tornaghi, 2014). Forging a path between naïve celebration and categorical dismissal, these authors engage urban agriculture's "simultaneous 
push pull of possibility and precariousness" (Philadelphia Food Policy Advisory Council, n.d., para. 5). McClintock (2014), for example, concludes "urban agriculture is not simply radical or neoliberal, but both, operating at multiple scales" (p. 165). While agriculture projects themselves cannot achieve systemic change, McClintock contends, the fact that urban agriculture has become increasingly institutionalized and incorporated into urban revitalization efforts nonetheless signals a paradigm change: the idea that cities should produce some of their own food has become a more widely shared norm.

Until recently, commercial urban agriculture has not attracted much attention from researchers. Market farming has typically been discussed as one of several manifestations of urban agriculture (e.g., Pearson, Pearson, \& Pearson, 2010). A pioneering exception was Kaufman and Bailkey's 2000 analysis of entrepreneurial urban agriculture, which drew on case studies of Chicago, Boston, and Philadelphia. Its discussion of the interplay between vacant land, entrepreneurial farms, and urban governance remains relevant to the discussion of city farming today. Equally insightful was its broad framing of entrepreneurial urban agriculture: not limited to profit-maximizing or even profit-seeking producers, the study placed as much weight upon "social service providers" as it did on "individuals with farm backgrounds" (Kaufman \& Bailkey, 2000, p. 6). This broad framing acknowledges U.S. urban agriculture's prevailing self-conception as social entrepreneurship combining for-profit farming with not-for-profit education and outreach endeavors, a framing that also informs recent studies (for examples, see Dimitri, Oberholtzer, \& Pressman, 2016; Sadler, Arku, \& Gilliland, 2015; Vitiello \& Wolf-Powers, 2014).

The same cannot be said for popular advocacy literature that promotes urban agriculture as a pathway to a livelihood for do-it-yourself farmers and is notably more vehement about urban agriculture as a commercial business proposition. One of these works declares: "With relatively little capital investment, unemployed citizens can turn vacant land into something productive in a relatively short time" (Hansen, Marty, \& Hansen, 2012, p. 8). Common to this advocacy literature are a few key recommendations, including selling to upscale restaurants and well-off consumers, minimizing capital and labor costs while maximizing production, and taking advantage of community supported agriculture (CSA) and marketing campaigns aimed at boosting demand for locally grown agricultural products (Cockrall-King, 2012; Hanson et al., 2012; Ladner, 2011; Lovell, 2010). However, the advocacy literature draws comparatively little attention to several substantial impediments to the profitability of city farming such as, for example, the high cost of land in many urban settings. Though not blind to high urban land values, market farming boosters point to the abundance of vacant lots in postindustrial cities. They argue that their private or municipal owners would be willing to lease or even donate land that might otherwise contribute to neighborhood blight, but these claims tend to gloss over the impermanence of many such agreements. It is true that farms add green space to neighborhoods, and, in turn, tend to raise the appraised value of the lots upon which they are established. However, as Wachter et al. (2010) have noted, that value nearly always pales in comparison to that of commercial or residential construction on those same lots. This is a contest city farmers rarely win: real estate development has displaced many urban farms, even widely lauded ones (Franceschini, Tucker, \& Hamersky, 2010). A further impediment to profitability is the existence of widespread heavy metal soil contamination in postindustrial cities. The relationship between soil contamination and food safety is complex, but assuaging consumer concerns and meeting regulatory requirements in many instances requires growing food intended for sale in raised beds filled with imported clean soil. Even when uncontaminated, many vacant lots in cities like Philadelphia have soil of such poor quality for farming that they require imported soil or several seasons of building up the current soil before produce can be grown there. The transience, by design or by default, of many city-farming operations, however, can make planning and financing these essential capital investments unrealistic.

Another thread running through the advocacy literature is reliance on the small plot intensive (SPIN) farming method as an example of a 
"proven, simple, and replicable business model" (Hansen et al., 2012, p. 76). The SPIN model provides a business plan, a marketing plan, and day-today work flow for the sub-acre farms typically found in urban agriculture. It is well known in Philadelphia's urban agriculture community because, in the early 2000s, the Philadelphia Water Department sponsored an experimental half-acre (.2 hectare) farm in Northeast Philadelphia called Somerton Tanks Farm, which operated for four years (Institute for Innovations in Local Farming [IILF] \& Urban Partners, 2007).. The report summarizing the results of this experiment concluded that a couple working together on six scattered-site farms, with the land totaling less than one acre (.4 ha), could gross US $\$ 120,000$ annually following five years of experience (IILF \& Urban Partners, 2007). However, that total is almost double what was grossed in the experimental farm's most profitable year-US $\$ 68,000$, while operating costs amounted to US $\$ 69,800$ including meager wages for the farmers-and was founded on much speculation about the degree of heightened productivity possible given a prolonged growing season and the employment of part-time labor (IILF \& Urban Partners, 2007). Moreover, SPIN assumes free or marginally priced land, a production rate of US $\$ 20$ of output per labor hour, and US $\$ 135,000$ in startup costs to be covered by grants from public or nonprofit agencies (IILF \& Urban Partners, 2007). From the perspective of many practicing urban farmers, however, there may be a more basic problem here: To what extent is the SPIN model consistent with the social goals that motivate most urban farmers? The report states that the "experimental and educational purposes" of the farm meant "efforts to maximize revenue were sometimes negatively impacted by these additional priorities" (IILF \& Urban Partners, 2007, p. 14). In order for participating farms to succeed as businesses, the SPIN method requires them to focus exclusively on production and revenue maximization. This can be achieved by targeting well-off customers and niche markets, which necessarily neglects low-wealth populations. Proponents of entrepreneurial urban agriculture are not unaware of the trade-offs between the entrepreneurial and social justice goals that motivate many urban farmers, but they frequently underestimate their severity. Lovell (2010), for example, notes that smallscale urban growers can become profitable by working with upscale niche markets while also asserting that these same farmers can meet demand for fresh produce among low-income consumers living in urban food deserts. Still, whether urban farmers can achieve their social and financial goals simultaneously remains far from clear. In this study, we explore the gap between what advocates claim is possible and what farmers on the ground are actually achieving in urban agriculture.

\section{Study Design}

In order to develop a nuanced understanding of factors that shape the financial viability of city farming, we conducted semi-structured interviews with twenty farmers and farm workers in the summer of 2014. We selected a survey design in part because we did not have the resources to undertake detailed financial audits of urban farms and, more importantly, because recruiting participants for such intrusive audits would have been impossible. This was a study produced with urban farmers, not just about them, in the tradition of participatory social science research. We were curious to learn what practitioners of urban agriculture had to say about its financial viability in a big picture sense. Self-reported financial and economic information has some limitations for producing a comprehensive farm-level economic analysis (e.g., farmers tend to undervalue their own labor), but this wasn't our goal. Rather, we sought to critically examine, in light of urban farmers' practical knowledge and experience, some of the more boosterish claims being made on behalf of entrepreneurial urban agriculture in the United States today. To that end, we approached urban market farmers as sources of information and insight about their work, contextualized by a review of the literature and informed by the research team's familiarity with urban agriculture in Philadelphia.

Study participants had to be involved in market farming, which excluded from consideration nonmarket community gardens. However, in keeping with existing research on urban agriculture, we 
took a flexible view of what urban production agriculture can entail by including both for-profit and nonprofit operations, as long as some crops were sold to the public. Fourteen urban farmers were recruited in Philadelphia. Approximately twenty city farms practice some form of market farming, ${ }^{2}$ resulting in estimated participation rate in our study of about $70 \%$. In addition, six rural and peri-urban farmers were recruited from within an eighty-mile radius of the city. Given the importance of farm size as a factor in farm profitability, we decided to include in our study somewhat larger commercial farms outside Philadelphia. The purpose for including rural and peri-urban farms in our study was to inform our understanding of urban agriculture; beyond that, we are wary of diluting the meaning of urban agriculture and therefore tabulate separate results for urban and peri-urban farms where appropriate.

Our informant interviews sought to elicit information about farm operations as well as participant meanings about urban agriculture in Philadelphia. We set out to obtain quantitative data on key factors with a bearing on the financial condition of urban farming. Our interview questions were selected following a review of the literature on urban agriculture and in response to feedback provided by Philadelphia urban farmers and Philadelphia County-Penn State Extension experts with whom we discussed a draft of the study design. Compiling, comparing, and analyzing the farmers' responses led us to identify ten farm-level and external factors that shape the financial viability of urban farming in Philadelphia, including: motivation for farming, business model, farm size, workforce composition, farm profitability, nonfarm income, fixed and/or startup costs, cost of land, crop-specific costs, and challenges of city farming. Some of these factors (e.g., motivation for farming, challenges of city farming) are less quantifiable than others; where appropriate, therefore, we frame our discussion of study results in terms of participant meanings rather than quantitative data. As we shall see, how farmers conceptualize urban agriculture significantly affects the degree to which

2 That estimate is based on a survey performed by the authors that excludes several farm-like community gardens where they consider profitability to be an important organizational objective.

To encourage study participants to speak freely, the interviews were not audio-recorded; however, detailed field notes were taken by two of the authors of this paper. We also assured study participants confidentiality. Since Philadelphia's urban farming community is characterized by internal competition for limited public and private funding opportunities, we do not disclose information that might make a farmer or their farm identifiable to a third party. The study received exempt status from Drexel University's Institutional Review Board. We attempted to collect a comprehensive set of responses from the greatest possible pool of interviewees, and we managed to talk to at least seventy percent of the city's farmers (as distinct from community gardeners). However, our interviews were conducted during the summer months, the height of the growing season and a time of year when farmers are very busy. Consequently, some of the farmers to whom we reached out were unable to participate in the study, and thus our findings do not provide as complete a picture of urban agriculture in Philadelphia as we might have wished for. Most notably, some farmers who were unable to participate in interviews were also those most involved in for-profit niche market farming. While these missing voices influence the results of this study to some extent, their omission, we believe, does not negate the validity of the input from those who were able to participate.

\section{Results and Discussion}

We begin our discussion of the financial viability of urban agriculture in Philadelphia with a summary of the participating farms' business models, sizes, and missions. This will contextualize the economic analysis that follows.

\section{Business Model}

Our sample included four for-profit farms and ten nonprofit farms in Philadelphia and five for-profit farms and one nonprofit farm outside Philadelphia. While for-profit farms seek to generate a financial

gardeners produce food primarily for their own consumption. 
profit for their owners, nonprofit farms aim to benefit the greater good of the community (Fritz, 2015). This difference is reflected in their tax status: a for-profit farm is taxed on its profits while a nonprofit farm is not. Additionally, due to the extent that nonprofit farms manage to secure grant funding to further their social goals, they may be able to rely on income sources other than their crop sales to sustain their farms.

One of the four for-profit farms in the city functions as the farming project of a larger organization with both for-profit and nonprofit programs; the other three are run by individual farmers. None of the for-profit urban farms we studied rely solely on farm income for their livelihood. At two of the three for-profit farms, the farmers work on the farm part-time and have supplemental sources of income, such as nonfarm employment by the farmer or a spouse. Bear in mind that this situation is not radically different from the economics of many rural farms whose owneroperators rely on part-time or full-time nonfarm employment to supplement their income and/or to access employer-provided health insurance. Moreover, agriculture does not function outside the context of public policy: the economic condition of rural and peri-urban agriculture is as much a result of state and federal agriculture policies as of the weather and farmers' business acumen. We do not assume, or want to imply, that urban farmers depend on government support while their nonurban counterparts have somehow figured out how to thrive in free-market conditions.

While some of the nonprofit farms are independent entities, several are part of larger nonprofit organizations, such as community development corporations or anti-hunger charities. This arrangement provides organizational support and may indicate something of a trend among community and economic development nonprofits to establish urban farms.

\section{Size}

There are roughly 40,000 vacant lots in Philadelphia, but the relatively high density of the city compared to the surrounding region means that most of these lots are small in size, typically much smaller than a traditional farm lot (City of Philadelphia, 2014). As a result, potential urban farmers generally do not have access to large contiguous tracts of land in Philadelphia. All of the city farms in our sample are smaller than five acres (2.02 ha), and most are smaller than one acre $(.4 \mathrm{ha})$. The larger urban farms are located along the city's periphery or adjacent to parks where there is more available land for cultivation, or they use scattersite models in which a single farm produces food on several smaller parcels. Unsurprisingly, all of the farms located outside the city exceed one acre (.4 ha), with only one farm smaller than five acres (2.02 ha). Two-thirds of these farms are larger than ten acres ( $4.05 \mathrm{ha})$, with the largest farm being forty acres $(16.19 \mathrm{ha})$. Though they are substantially larger than the urban farms we studied, our nonurban farms are small by rural farm standards. These farms produce a mix of vegetable crops comparable to the urban farms in our study; they are not commodity crop operations. We included them to open up some intellectual space for thinking about expanding the scale of urban agriculture. Theoretically, production farms between five and ten acres (between 2.02 and $4.05 \mathrm{ha}$ ) could be established on reclaimed brownfields, though turning over parcels of this magnitude to food production would go beyond the tentative paradigm shift in urban planning and municipal land-use policy identified by McClintock (2014).

\section{Mission}

Nearly all of the farmers participating in this study expressed diverse motivations for farming, with most offering multiple responses to the question "Why are you farming?," as shown in Figure 1. Farmers outside the city, particularly the for-profit farms, have different missions from those farming in Philadelphia. These rural farmers cited primarily a desire to preserve farming, a passion for farming and food, or a desire to provide wholesome food to customers as their motivations for farming. They also hoped to make a living by farming, but the financial situation of small farms is generally precarious (see, for example, Moyer, 2015). Not surprisingly, our one nonurban, nonprofit farm's primary mission is socially driven: to strengthen the community and increase food security through 
sustainable agriculture. This farm is closer to the city than the other participating nonurban farms: it is peri-urban rather than strictly rural.

Though a passion for farming and a desire to provide wholesome food cut across rural and urban farmers, nearly all of the latter cited explicitly social goals as having motivated their entry into urban agriculture. Even the two urban farms that described themselves as an "example" or an "experiment" to determine the viability of entrepreneurial urban agriculture either also had nonprofit status or were associated with nonprofits that had community development or educational goals. In fact, while the three for-profit urban farmers all noted their passion for farming as main drivers of their pursuit of urban agriculture, two of the three also mentioned the role of urban agriculture in "urban greening," meaning increasing the cover of vegetation in the urban built environment, as a part of their missions. One for-profit farmer further described a desire to increase his connection with his neighbors and to help community members by improving their access to affordable produce as two primary motives for starting his farm. For the most part, then, the for-profit urban farmers seem to share with their nonprofit counterparts a vision of urban farming that goes beyond just making a living. This finding affirms urban agriculture's social enterprise orientation independently of a farm's tax status.

Among nonprofit urban farms, the most commonly stated missions were covered by the categories of "food justice," "education," and "community." These categories are fairly broad, and also include some overlap. Food justice is defined as "ensuring that the benefits and risks of where, what, and how food is grown and produced, transported and distributed, and accessed and eaten are shared fairly" (Gottlieb \& Joshi, 2010, p. 6). Within the context of urban agriculture, most farmers working toward food justice goals describe a desire to increase access to nutritious produce in areas where it is otherwise unavailable or unaffordable to low-wealth communities. These farms are either located in low-wealth neighborhoods that lack sufficient access to full-service grocers, or they sell produce at subsidized prices at farmers' markets in these neighborhoods.

Several of the nonprofit urban farms described "education" as their primary mission. Education here refers largely to teaching children and teenagers about farming, environmental sustainability, and food justice through programs run on their farms. These programs also aim to provide youth mentorship and job readiness training, typically by way of farm internships or part-time employment for teenagers. The farms with this educational focus vary in the number of youths they work with and for how long, from offering one-day school field trips to weeks-long classes to multiyear internships for a handful of students.

These urban farmers see their food justice and educational goals, as well as urban greening objectives, as a means to further community development, the most common response to the question of the urban farms' missions. These farms are located in city neighborhoods that have experienced several decades of economic disinvestment along with persistent poverty, and the organizations managing the farms hope to use them as a

\section{Figure 1. Organizational Missions of the Farms in the Study}

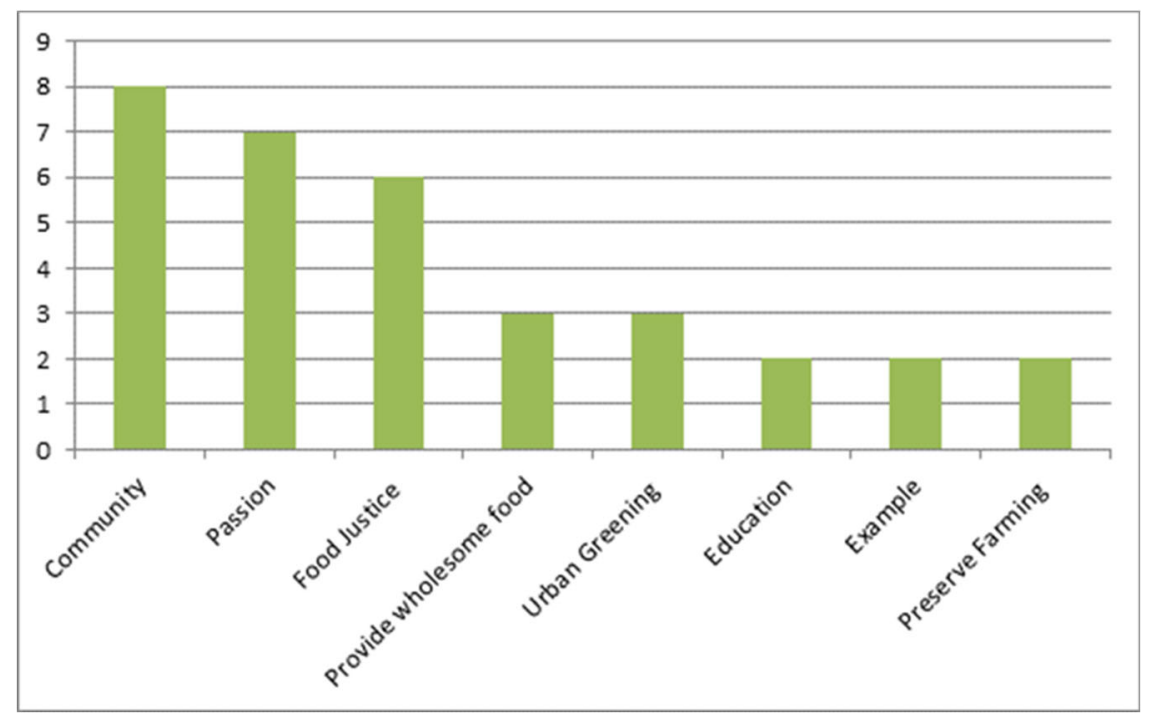


means to create safe and beautiful spaces where neighborhood residents can come together to create and enhance social capital. For these nonprofit farms, rehabilitation of vacant land, education and outreach, and food justice work all contribute to building more empowered and cohesive communities in these neighborhoods.

The sorts of missions revealed here suggest that most of the farmers interviewed for this study, but particularly the urban farmers, regard the financial viability of farming not as an end in itself but as a means to realizing wider social goals. As one longtime Philadelphia farmer put it: "It's never just about the food!" These results underline that urban agriculture here mirrors the social enterprise orientation of urban agriculture in the United States more generally. This context sets the stage for our economic analysis of urban agriculture.

\section{Economic Benchmarks}

Table 1 displays the economic metrics obtained from our farmer interviews. Sample size varies for different metrics because not all farmers were willing or able to provide information on all metrics. Metrics such as size, full-time equivalent (FTE) per acre, labor cost per FTE, labor cost per acre, capital investment per acre, land cost, farm gross receipts, receipts per acre, and receipts per FTE inform our economic analysis of urban farms with different business models and missions. They can serve as benchmarks based on data as opposed to assumptions derived from models.

The sizes of the farms studied range from 0.05 acres (.02 ha) to 40 acres (16.19 ha). Although a rural 40 -acre farm is obviously much larger than the urban farms in our study, including it helped us compare the economics of differently sized farms and determine what factors make smaller farms different from the bigger ones. Even in small-scale farming size matters, and some scales may simply be too small for market farming to be profitable.

The FTE per acre was determined using 60 hours per week corresponding to one FTE. Although 60 hours is $50 \%$ longer than the standard 40-hour work week, it is consistent with the number of hours full-time farmers reported they worked. Figure 2, which plots FTE against size, shows considerable variability for small farms. The correlation of 0.84 between size and FTEs is moderately strong and highly significant $(p$ value $<0.01)$. While there clearly is a positive association between size and employees, it is not a precise relationship with farms ranging from two to three acres (.81 to $1.21 \mathrm{ha}$ ) in size having as few as 0.5 FTE to as many as 7 FTEs. This variability may result not only from variability in business operations, with some farms concentrating on agricultural production and others devoting considerable effort to value-added, hence laboradded, products. It may also be the case that some

Table 1. Summary of Economic Metrics of the Farms in the Study

\begin{tabular}{|c|c|c|c|c|c|c|c|}
\hline Metric & Unit & $\begin{array}{c}\text { Sample } \\
\text { Size }\end{array}$ & Mean & Median & $\begin{array}{l}\text { Standard } \\
\text { Deviation }\end{array}$ & Minimum & Maximum \\
\hline Size & Acre & 20 & 6.1 & 1.7 & 11 & 0.05 & 40 \\
\hline FTE per acre & FTE/acre & 20 & 2.3 & 1.4 & 2.4 & 0.063 & 9.4 \\
\hline Labor cost per FTE & US\$/FTE & 12 & 15,000 & 15,000 & 13,000 & 0 & 31,000 \\
\hline Labor cost per acre & US\$/acre & 12 & 38,000 & 11,000 & 46,000 & 0 & 110,000 \\
\hline Volunteer labor & $\%$ & 18 & 16 & 0.82 & 31 & 0 & 100 \\
\hline Capital investment per acre & US\$/acre & 10 & 110,000 & 0 & 190,000 & 0 & 600,000 \\
\hline Land cost & US\$ & 12 & 91,000 & 600 & 220,000 & 0 & 700,000 \\
\hline Farm gross receipts & US\$ & 12 & 28,000 & 5,900 & 58,000 & 680 & 200,000 \\
\hline Receipts per acre & US\$/acre & 12 & 26,000 & 11,000 & 33,000 & 2100 & 110,000 \\
\hline Receipts per FTE & US\$/FTE & 12 & 13,000 & 3,500 & 16,000 & 700 & 53,000 \\
\hline
\end{tabular}

a $\mathrm{FTE}=$ Full-time equivalent staff position 
farms sought primarily to maximize efficiency of production while others were oriented more toward community engagement activities, such as youth training programs. This is suggested by the fact that the points for the for-profit farms tend to lie to the right of the points for nonprofit farms in Figure 2. The average FTE/ acre is higher for nonprofits than for for-profit farms (2.7 vs. 1.8), but this difference is not statistically significant ( $p=0.4$ for independent samples ttest).

Farm gross receipts versus FTE are shown in Figure 3. There is a modest and statistically nonsignificant correlation of 0.50. One might expect receipts and FTEs to be more tightly correlated given that labor is a major production cost, particularly for small-scale farming. The solid line indicates a slope of approximately US\$50,000/FTE, which corresponds roughly to the most favorable performance observed here. The point located just above the solid line at roughly $\mathrm{FTE}=4$ and receipts $=$ US $\$ 200,000$ just barely exceeds this benchmark. We propose $\$ 50,000$ per FTE as a benchmark representing a rough estimate of the upper bound of observed performance. A reasonable number of farms approach this benchmark (that is, they are located close to the solid line), but many are well Equivalent Workers

\section{Figure 2. Correlation of Number of Full-Time Equivalent Workers and Farm Size}

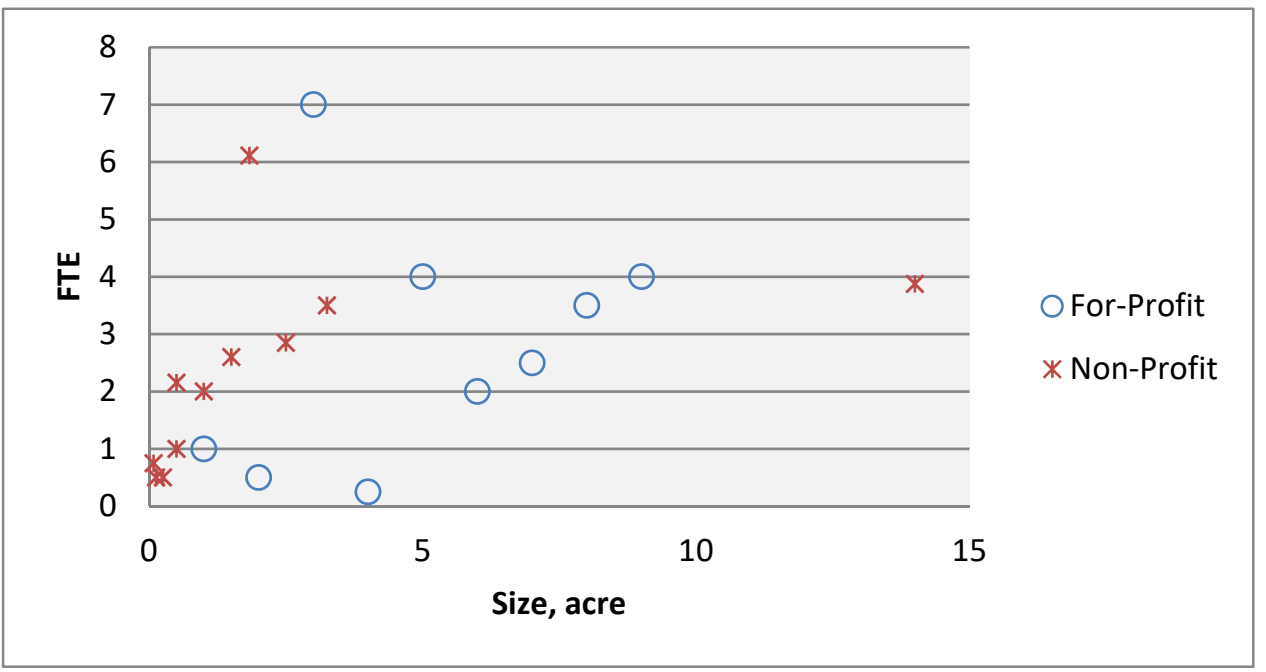

Figure 3. Correlation of Farm Gross Receipts and Number of Full-Time

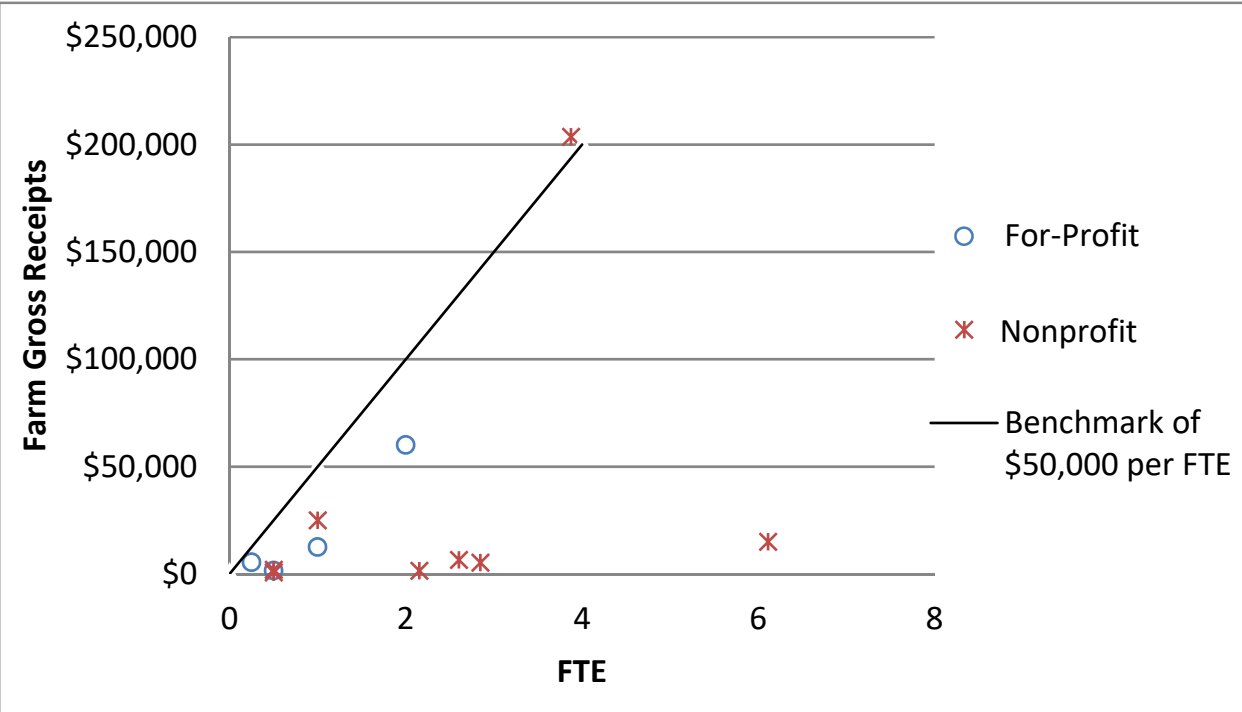

below it. Farms may fall below this line for a variety of reasons including both capabilities (how efficiently they operate) and mission (how important farm revenue is to their objectives).

Farm gross receipts versus size are shown in Figure 4. There is a modest and statistically nonsignificant correlation of 0.54 between these two metrics. One might have expected that in a spaceconstrained urban environment, there would be pressure to uniformly maximize returns from available space. But insofar as there is great variation in the revenue obtained per acre, the data 
Figure 4. Correlation of Farm Gross Receipts (US\$) and Farm Size (Acres)

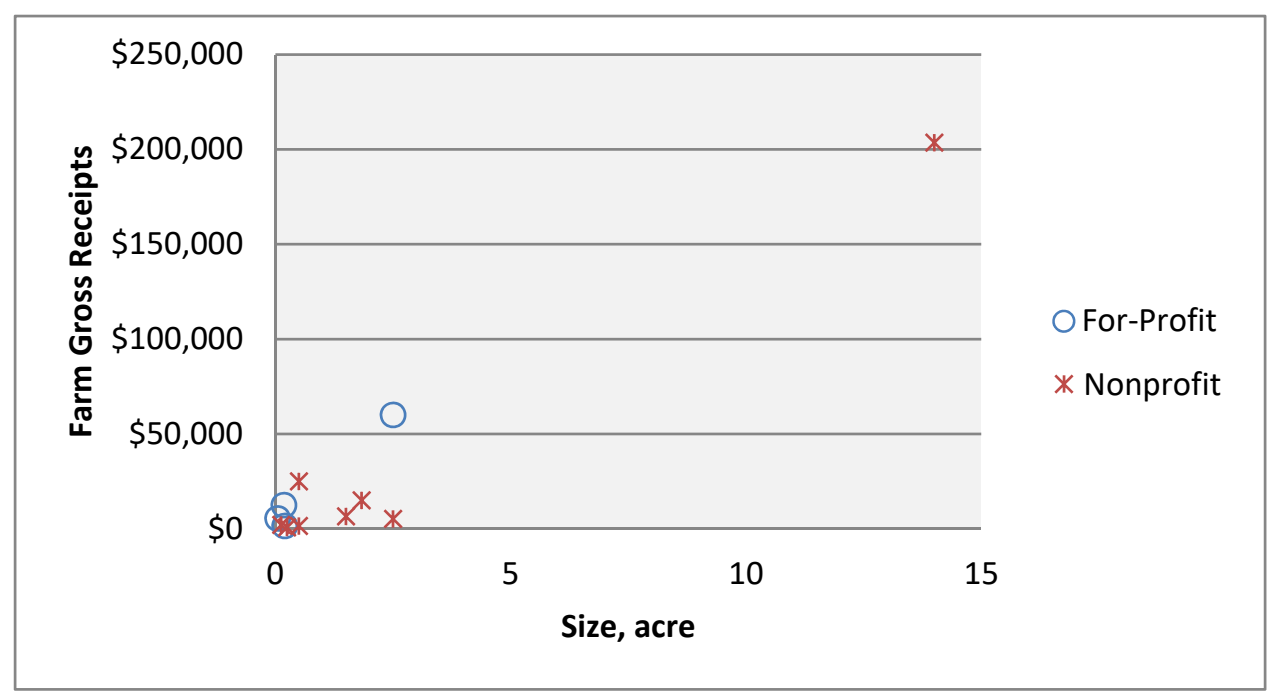

Figure 5. Correlation Between Capital Investment (US\$) and Farm Size (Acres)

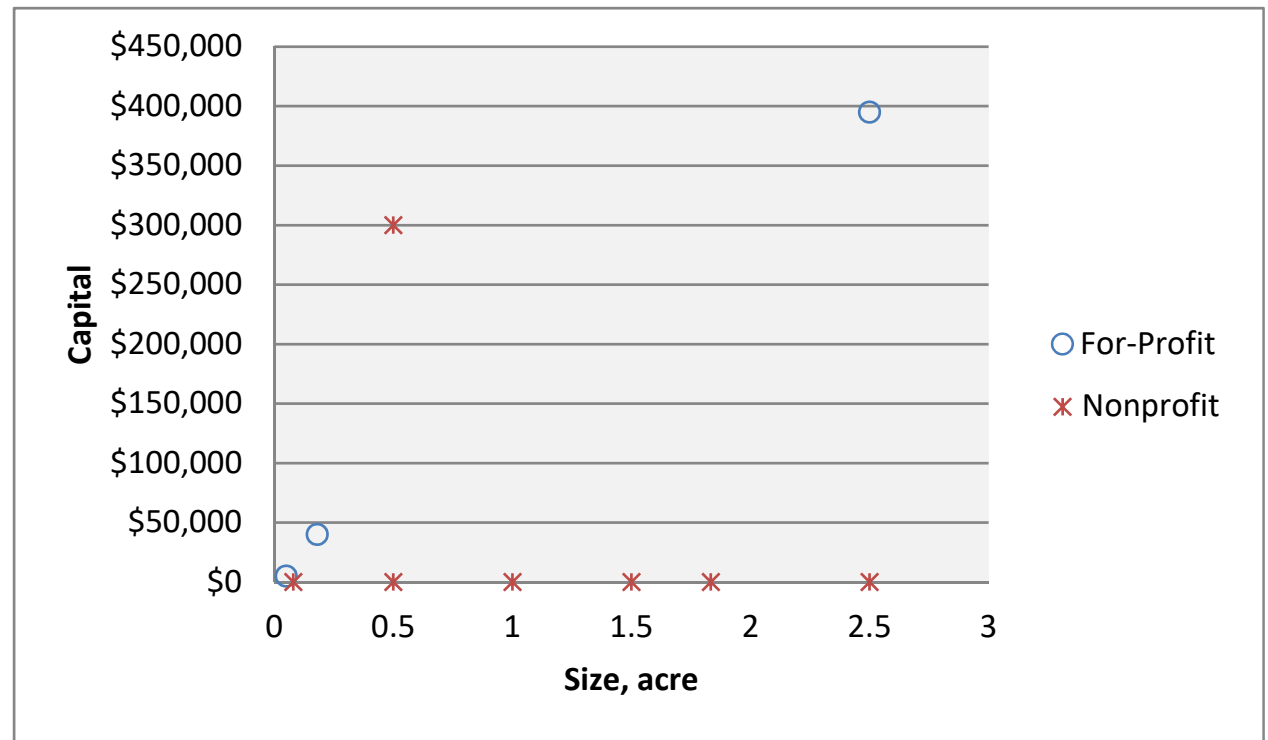

nonprofit farm

showed a nonzero

capital investment.

\section{Profitability and}

Viability of Urban

Agriculture

According to our interviewees' assessments of the profitability of their farms, six of the 14 farms in Philadelphia made a profit, five posted losses, and three broke even (Table 2). Profitability here does not, for the most part, account for labor costs. If labor costs are accounted for, only one of the 14 urban farms could be counted as profitable (not fully accounting for labor and a reliance on unpaid labor are common practices in city farming, see Biewener, 2016). This farm was somewhat unusual, moreover, in that it consisted of a single farmer growing microgreens in a garage. What made it

suggest otherwise. As with the other metrics examined, this variability probably reflects variation in both farming practices and organizational mission. Put differently, social-service oriented farms may sacrifice some food production to other goals.

Figure 5 is a scatter plot of capital (land and equipment) versus size that shows that for the forprofit farms, the bigger the farm, the bigger the capital investment. This is very much not the case for the nonprofit farms in our study, most of which show a capital cost of US $\$ 0$ because most or all of their equipment was donated. Only one profitable was the farmer's focus on producing a high-value specialty crop (Lyne, 2012) combined with the rent-free availability of the garage, which provided important temperature control that expanded the growing season. The capital costs of the garage construction and opportunity costs of the land were not included in this assessment of profitability. Moreover, given that a single individual was both the business owner and sole employee, the distinction between wages and profit is not entirely clear, but returns appear to have been relatively favorable for a part-time effort. This 
may serve as an example of urban agriculture's occasional ability to profitably occupy micro-niches of unexploited capital assets — up to a point. This approach is inherently non-scalable, given that larger assets sitting idle (land, buildings) typically attract more competition from alternative uses. In fact, this farm ended operations when the garage became unavailable. As for the rural and peri-urban farms, four were profitable and two broke even, but, again, not all of the profitable operations accounted for labor costs. The tendency of farmers to undervalue their own labor holds true across the urban and rural farms in our study.

The farmers in the study were also invited to share with us their thoughts on the economic prospects of urban agriculture beyond the performance of their own farms. None of the farmers we interviewed believed that urban agriculture was economically viable today, but they were evenly split on its future potential. Six thought that urban agriculture could never be economically successful (five urban farmers and one peri-urban farmer), but seven urban farmers suggested that economic success might be achieved in a more supportive financial and policy environment.

\section{Challenges in Urban Farming}

To discover what problems that could be addressed by a more supportive financial and policy environment, we asked our participants to describe what they saw as their biggest challenges in urban farming. Of eighteen respondents to this question, some indicated one main challenge while others
Figure 6. Biggest Farmer-Identified Challenges in Urban Farming

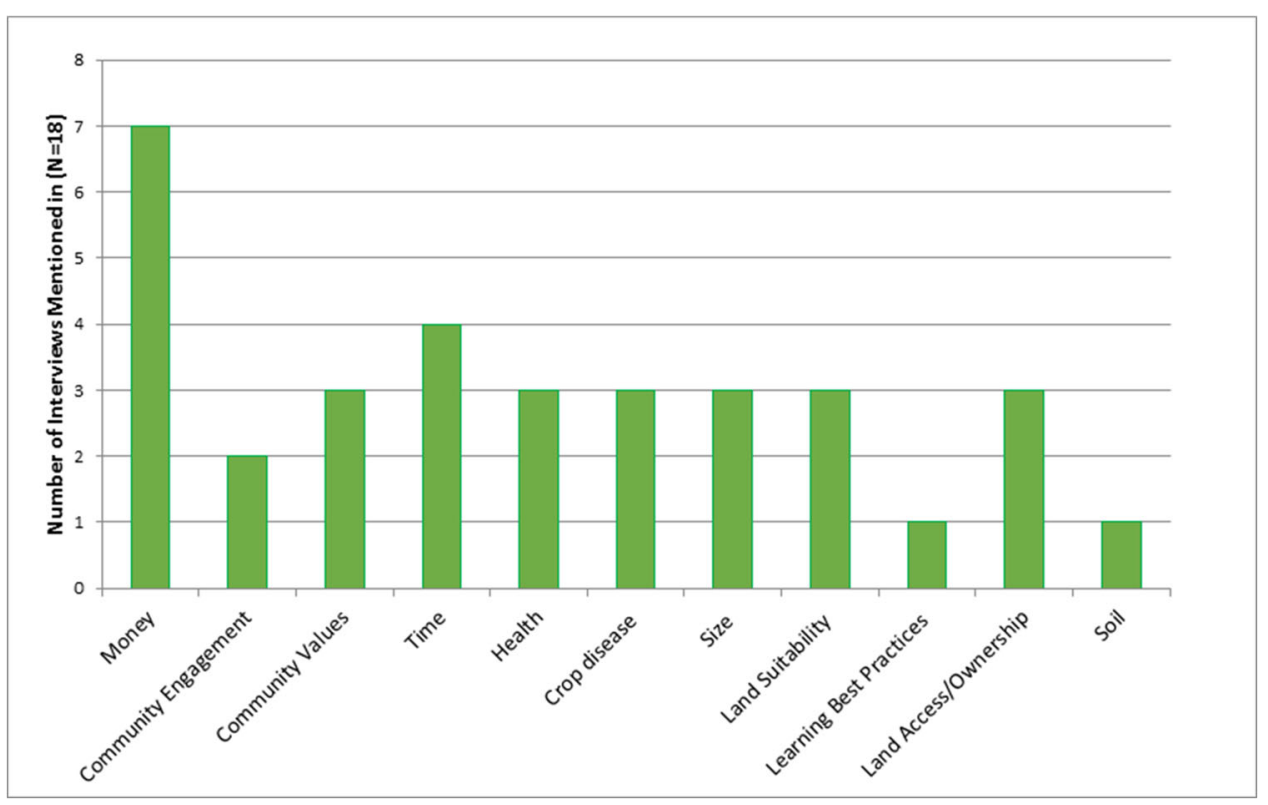


and not being accounted for. Based on the four farmers who provided nonzero estimates of capital costs, the average capital cost per acre was US $\$ 270,000$ and the median was US $\$ 190,000$. The average of US $\$ 270,000$ corresponds to annual payments of US $\$ 22,000$ dollars at $7 \%$ interest over 30 years (Office of Management and Budget, n.d., p. 9). However, access to financing on the private capital market is all but nonexistent for urban farms. To quote one of the farmers, "[Unless] you can prove to the bank that farming is profitable, no bank wants to take that risk and give you a loan." Since financial institutions consider urban farming to be unprofitable, it is impossible to secure commercial loans. At the same time, obtaining grants, upon which most nonprofit farms rely to stay afloat, is a highly competitive and time-consuming process. One farmer indicated having to "fight for funding each year," and expressed concern about constantly having to ensure that the farm's mission remained relevant to potential funders. Thus, unless an urban farmer is independently wealthy or grant-supported for a number of years, assuring a farm's financial sustainability is a challenge.

\section{Time}

Four farmers reported that time was one of their biggest challenges. In this study, we considered the full-time equivalent (FTE) to be 60 hours of work. A Pearson correlation of 0.885 implies a very

\section{Figure 7. Main Agricultural Capital Costs According to Interviewees}

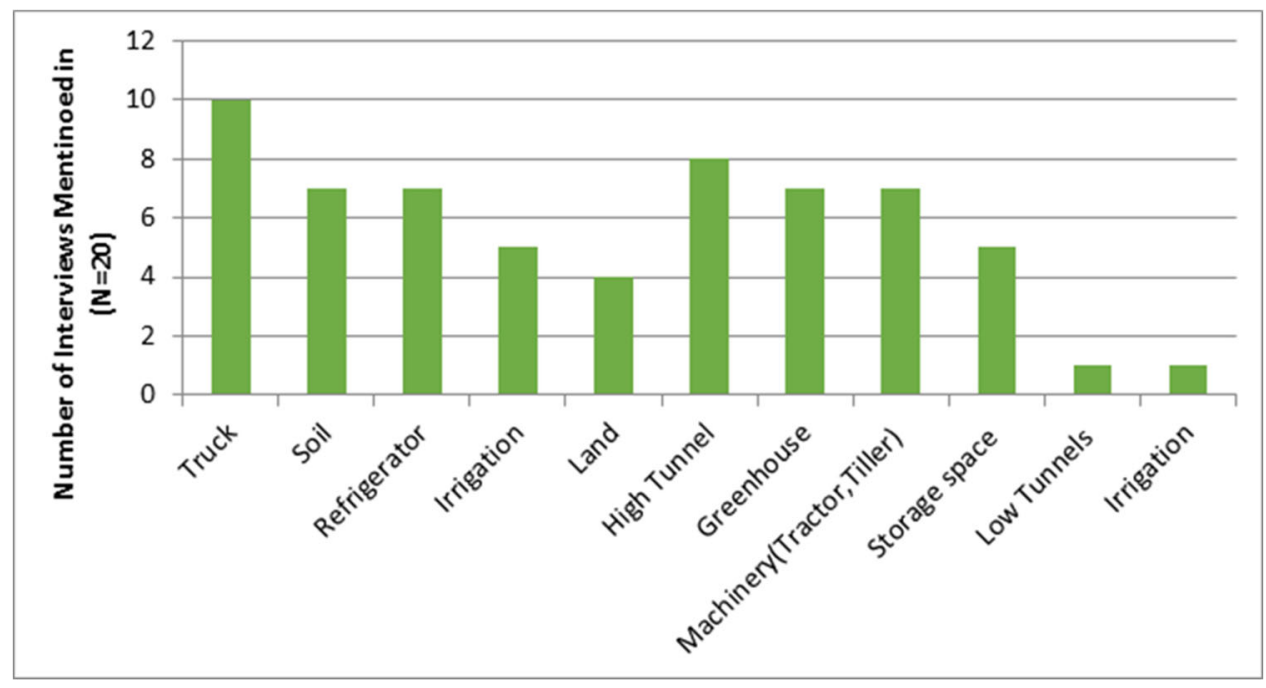

strong positive correlation between FTE and farm total yield. As FTE increases, farm total yield also increases, which suggests that the amount of time farmers can invest in cultivating their crops has a big influence on the yield at the end of the season. There is limited potential to enhance labor productivity through farm machinery. In order to maximize productivity in limited space, small-scale farming - including much of urban agriculturetends to involve intensive and highly diversified crop production techniques that often cannot be done with large machinery, meaning that the labor is typically manual (Philips, 2013).

\section{Health}

Three farmers responded that health was a main challenge, though these are the nonurban farms that are not grant-funded and have the farm as their sole source of income. A farmer who gets sick or gets hurt on the job may be unable to work. Part of health being a challenge is the high cost of health care and health insurance, notwithstanding the Affordable Care Act.

\section{Land Tenure}

Table 3 shows the pattern of land ownership among the farms we studied. Five of the for-profit farms own their land and the others either partly own and partly lease or just lease it. The land cost for the for-profit 10-acre (4.05 ha) farm includes

the house on the property (Figure 8). The 40-acre (16.19 ha) farm was purchased in the early 1950s at auction and was later inherited. Interestingly, only one out of the five forprofit farms that own the land is actually making a profit. As discussed above, land is a major capital expense, but the form of tenancy appears to be unrelated to profitability in our sample. 
Table 3. Forms of Land Tenure of the Farms in the Study

\begin{tabular}{l|c|c|c|c|c}
\hline & Owned & Owned/Leased & Leased & Leased-\$1/yr & Leased/Free \\
\hline For-profit & 5 & 2 & 2 & 0 & 0 \\
\hline Nonprofit & 2 & 0 & 1 & 3 & 5 \\
\hline
\end{tabular}

Figure 8. Correlation Between Cost of Land and Amount of Land Owned

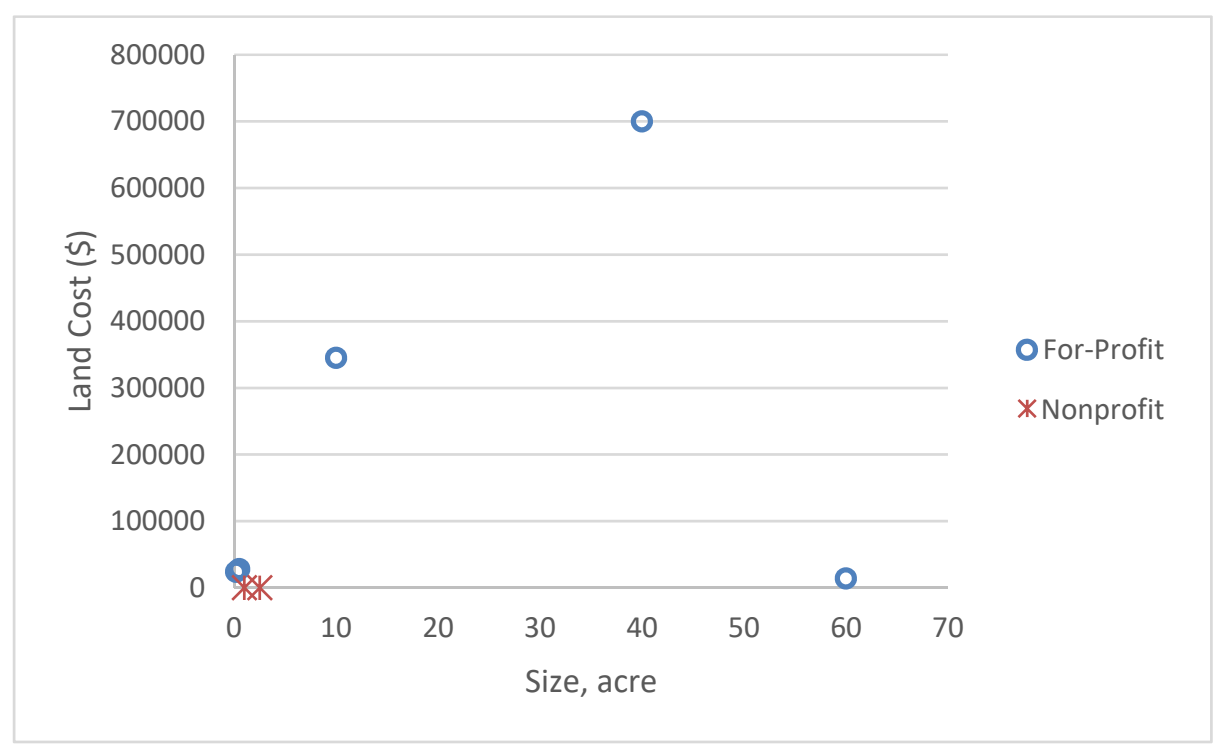

awareness of Americans around food?" Unfamiliarity with urban farming and the nutritional benefits of fresh produce can be a barrier to community buy-in (see Poulsen, Spiker, \& Winch, 2014). Ironically, then, even though socially motivated farms aim to use urban agriculture to improve their communities, persuading neighborhood residents of the desirability of locally grown produce may be unexpectedly difficult.

\section{Conclusion}

The results of our exploratory study are consistent with claims that urban agriculture cannot meet important and ambitious food

\section{Community}

While community improvement was the primary mission of a number of the nonprofit urban farms, several farms acknowledged that getting support from the surrounding community or convincing the community of the importance of urban agriculture were also some of their greatest challenges. A few farmers expressed frustration that one barrier to achieving their food justice goals was their intended customers' apparent lack of interest in the fresh produce grown on their farm. One farmer lamented that neighborhood residents believed supermarket food to be of higher quality than that sold at a farm stand, despite the farm stand produce being significantly fresher and organically produced. Another farmer commented that many farm stand customers from the community requested fruit unsuited to the region's climate that could not be produced locally. Concerning the lack of interest from the community in the food available at the farm stand, one farmer asked, "what do we need to do to raise the level of justice, social capital, and job creation goals "while also being financially sustainable without outside funding” (Daftary-Steel, Herrera, \& Porter, 2015). In closing, we briefly consider our findings in terms of the SPIN model discussed in the background section of this paper. The farmers were asked about their familiarity with and thoughts about the SPIN model. Those who knew of the model (a majority) thought it was not realistic because in their own experience the well-oiled farm assumed to exist by the model did not-and arguably could not-exist in practice. A key assumption in the SPIN model is that the soil to be farmed is productive and not contaminated, which avoids the capital costs of either cultivating the soil for several seasons prior to starting production or of constructing raised beds and importing soil. SPIN also does not include structures to extend the growing season, either greenhouses or high tunnels, which farmers reported as being very helpful, if not indispensable in Philadelphia's climate. Another element of the SPIN model considered impractical by the 
farmers we interviewed was irrigation. In the model, the source of water for irrigation is city water, reliance on rainfall, and free use of water supplied by one of the landlords. In reality, reliable access to water is one of the key challenges in running an urban farm. Philadelphia Water does not deliver city water to vacant lots, for example. While some farms in our sample do have access to city water, others rely on some combination of rainfall and rainwater catchment systems, whose construction requires capital expenditures, unless they are donated by a university or by another institutional partner.

Whether capital costs need to be paid by the farm will have a substantial impact on its viability, of course. The maximum value found in our study for gross receipts per FTE was US $\$ 53,000$. This would be sufficient to cover capital costs (annualized at US $\$ 22,000$ per year for a one-acre (.4 ha) farm, see "Capital Requirements" section above) and still pay wages of around US $\$ 30,000$. The second highest of the twelve reported values of receipts per FTE was US\$30,000, which is clearly insufficient to both cover capital costs and pay a living wage. In light of these discrepancies between the model and our data, we can imagine three paths for making urban farming economically more sustainable. One possibility is for the peak performance of US $\$ 53,000$ per acre we have observed to be widely replicated. Our study suggests that the SPIN values are not impossible to achieve, but they appear to be economically more ambitious than the typical urban farm performance observed here. A second possibility is for urban farms to exist and operate only in niches where capital costs are already largely covered by happenstance. This path is consistent with the original intent of much of urban farming to productively use vacant spaces. The temporary success of one farmer using a garage to grow microgreens implies that creative farmers may well find ways to implement this strategy, but the unsustainability of that effort once the garage was needed for another use by its owner also illustrates the potential fragility of such efforts.

A third option is that if the nonmarket benefits of urban agriculture such as "deeper concerns of equity, citizenship, place-building, and sustaina- bility" (DeLind, 2011, p. 273) are judged to be sufficiently important to justify support for the practice, then capital costs might be covered through a one-time grant from either a governmental or foundation source. In this case, a much larger set of farms could become financially sustainable, without having to become larger or exclusively profit-oriented operations. Of the twelve farms reporting values, four had receipts per FTE of greater than US $\$ 20,000$ per year, a level that appeared viable to attract qualified workers. Urban agriculture may not be the preferred land use expressed by market valuations, but the nonmarket benefits of urban farms may persuade public agencies and private foundations who seek to strengthen urban food networks to include agriculture as an urban land use in a fashion sustainable for the long term. This third option would have the added advantage of being consistent with both the multiple functions and goals of city farming in the United States and with the practical experiences of many urban farmers, both of which point to a more tempered judgment about the commercial prospects of small-scale urban market farming than a perusal of the breathless advocacy literature would seem to suggest. Opportunities for building on this research include examining the financial sustainability of urban agriculture in other cities: factors such as real estate development pressure and the amount and cost of available land may differ sufficiently among cities to produce very different cost structures for urban market farming. Along similar lines, a comparative analysis of policies intended to support entrepreneurial urban agriculture in cities across the United States would be extremely valuable.

\section{Acknowledgments}

We would like to thank Drexel University's Urban Sustainability Initiative for funding this project, the Penn State Extension Philadelphia office for assisting us in contacting interview participants, and the farmers who shared their knowledge with us. In addition, we are grateful to the JAFSCD reviewers for their thoughtful comments on earlier drafts of this article. 


\section{References}

Allen, P., \& Guthman, J. (2006). From 'old school' to 'farm-to-school': Neoliberalization from the ground up. Agriculture and Human Values, 23(4), 401-415. http://dx.doi.org/10.1007/s10460-006-9019-z

Biewener, C. (2016). Paid work, unpaid work, and economic viability in alternative food initiatives: Reflections from three Boston urban agriculture endeavors. Journal of Agriculture, Food Systems, and Community Development, 6(2), 35-53. http://dx.doi.org/10.5304/jafscd.2016.062.019

City of Philadelphia. (2014). V acant lot program. Retrieved January 21, 2015, from http://www.phila.gov/ qualityoflife/vacantlotprogram/Pages/default.aspx

Classens, M. (2015). The nature of urban gardens: Toward a political ecology of urban agriculture. Agriculture and Human Values, 32(2), 229-239. http://dx.doi.org/10.1007/s10460-014-9540-4

Cockrall-King, J. (2012). Food and the city: Urban agriculture and the new food revolution. Amherst, New York: Prometheus Books.

Daftary-Steel, S., Herrera, H., \& Porter, C. M. (2015). The unattainable trifecta of urban agriculture. Journal of Agriculture, Food Systems, and Community Development, 6(1), 19-32. http://dx.doi.org/10.5304/jafscd.2015.061.014

DeLind, L. B. (2011). Are local food and the local food movement taking us where we want to go? Or are we hitching our wagons to the wrong stars? Agriculture and Human Values, 28(2), 273-283. http://dx.doi.org/10.1007/s10460-010-9263-0

Dimitri, C., Oberholtzer, L., \& Pressman, A. (2016). Urban agriculture: Connecting producers with consumers. British Food Journal, 118(3), 603-617. http://dx.doi.org/10.1108/BFJ-06-2015-0200

Franceschini, A., Tucker, D., \& Hamersky, A. (2010). Farm together now: A portrait of people, places, and ideas for a new food movement. San Francisco, California: Chronicle Books.

Fritz, J. (2015, January 1). How is a nonprofit different from a for-profit business? Getting beyond the myths. Retrieved from https://www.thebalance.com/how-is-a-nonprofitdifferent-from-for-profit-business-2502472

Gottlieb, R., \& Joshi, A. (2010). Food Justice. Cambridge, Massachusetts: MIT Press.

Guthman, J. (2008). Neoliberalism and the making of food politics in California. Geoforum, 39(3), 1171-
1183.

http://dx.doi.org/10.1016/i.geoforum.2006.09.002

Hanson, D., Marty, E., and Hanson, M. (2012). Breaking through concrete: Building an urban farm revival. Oakland: University of California Press.

Institute for Innovations in Local Farming [ILF] \& Urban Partners. (2007). Farming in Philadelphia: Feasibility analysis and next steps. Philadelphia, Pennsylvania. Retrieved from http://www. urbantilth.org/wp-content/uploads/2008/09/ urban-farm-business-incubator.pdf

Kaufman, J., \& Bailkey, M. (2000). Farming inside cities: Entrepreneurial urban agriculture in the United States (Working Paper WP00JK1). Cambridge, Massachusetts: Lincoln Institute of Land Policy.

Kingsley, J., \& Townsend, M. (2006). "Dig in" to social capital: Community gardens as mechanisms for growing urban social connectedness. Urban Policy and Research, 24(4), 525-537. http://dx.doi.org/10.1080/08111140601035200

Ladner, P. (2011). The urban food revolution: Changing the way we feed cities. Gabriola Island, British Columbia: New Society Publishers.

Lindy, R. (2015). Carrots in concrete and corner stores: Two analyses of tools to mitigate urban food insecurity (Unpublished honors thesis). Wesleyan University, Middletown, Connecticut.

Lovell, S. T. (2010). Multifunctional urban agriculture for sustainable land use planning in the United States. Sustainability, 2(8), 2499-2522. http://dx.doi.org/10.3390/su2082499

Lyne, D. (2012, October 23). Small plots produce nice profits for niche farmers. Fauquier Now. Retrieved from http://www.fauquiernow.com/index.php/ fauquier_news/article/small-plots-produce-niceprofits-for-niche-farmers

McClintock, N. (2014). Radical, reformist, and gardenvariety neoliberal: Coming to terms with urban agriculture's contradictions. Local Environment, 19(2), 147-171. http://dx.doi.org/10.1080/13549839.2012.752797

McGovern, S. J. (2009). Mobilization on the waterfront: The ideological/cultural Roots of potential regime change in Philadelphia. Urban Affairs Review, 44(5), 663-694. http://dx.doi.org/10.1177/1078087408323943 
Moyer, J. (2015, February 9). What nobody told me about small farming: I can't make a living. Salon. Retrieved from http://www.salon.com/2015/02/ $10 /$ what nobody told me about small farming i cant make a living/

Nordahl, D. (2009). Public produce: The new urban agriculture. Washington, D.C.: Island Press.

Office of Management and Budget (n.d.). Guidelines and discount rates for benefit-cost analysis of federal programs (Circular No. A-94). Retrieved from https://obamawhitehouse.archives.gov/sites/ default/files/omb/assets/a94/a094.pdf

Pearson, L. J., Pearson, L., \& Pearson, C. J. (2010). Sustainable urban agriculture: Stocktake and oppportunities. International Journal of Agricultural Sustainability, 8(1-2), 7-19. http://dx.doi.org/10.3763/ijas.2009.0468

Philadelphia Food Policy Advisory Council (n.d.). Testimony in support of urban agriculture. Retrieved from http://www.pilcop.org/wpcontent/uploads/2016/09/FPAC-Urban-AgHearing-Testimony-Sep-21-2016.pdf

Philips, A. (2013). Designing urban agriculture: A complete guide to the planning, design, construction, maintenance, and management of edible landscapes. Hoboken, New Jersey: Wiley.

Poulsen, M. N., Spiker, M. L., \& Winch, P. J. (2014). Conceptualizing community buy-in and its application to urban farming. Journal of Agriculture,
Food Systems, and Community Development, 5(1), p161-178.

http://dx.doi.org/10.5304/jafscd.2014.051.014

Sadler, R. C., Arku, G., \& Gilliland, J. A. (2015). Local pfood networks as catalysts for food policy change to improve health and build the economy. Local Environment: The International Journal of Justice and Sustainability, 20(9), 1103-1121. http://dx.doi.org/10.1080/13549839.2014.894965

Tornaghi, C. (2014). Critical geography of urban agriculture. Progress in Human Geography, 38(4), 551567. http://dx.doi.org/10.1177/0309132513512542

Vitiello, D., \& Nairn, M. (2009). Community gardening in Philadelphia: 2008 harvest report. Retrieved from http://www.farmlandinfo.org/sites/default/files/ Philadelphia Harvest 1.pdf

Vitiello, D., \& Wolf-Powers, L. (2014). Growing food to grow cities? The potential of agriculture for economic and community development in the urban United States. Community Development Journal, 49(4), 508-523. http://dx.doi.org/10.1093/cdj/bst087

Wachter, S., Scruggs, G., Voith, R., \& Huang, L. (2010). Redevelopment authority of the City of Philadelphia: Land use and policy study. Philadelphia: Penn Institute for Urban Research and Econsult Corporation.

Winne, M. (2009). Closing the food gap: Resetting the table in the land of plenty. Boston, Massachuetts: Beacon Press. 